\title{
Phytoplankton activity in enclosed and free marine ecosystems in a southern Norwegian fjord during spring 1979*
}

\author{
J. Jahnke ${ }^{1}$, U. H. Brockmann ${ }^{2}$, L. Aletsee ${ }^{1}$ and K. D. Hammer ${ }^{2}$ \\ ${ }^{1}$ Institut für Biologie I (Botanik), Abteilung für Systematik und Geobotanik, RW Technische Hochschule Aachen, Melaten, \\ Worringerweg, D-5100 Aachen, Federal Republic of Germany \\ ${ }^{2}$ Institut für Organische Chemie und Biochemie, SFB 94, Universität Hamburg, Martin-Luther-King-Platz 6, D-2000 Hamburg \\ 13, Federal Republic of Germany
}

\begin{abstract}
Primary production was estimated during enclosure experiments in a southern Norwegian fjord during POSER in spring 1979. The measurements were supplemented by analyses of phytoplankton from the fjord, enclosed natural plankton communities, and nutrient enriched monocultures of the dominant diatoms Thalassiosira nordenskioeldii, Chaetoceros debilis and Skeletonema costatum. Phytoplankton activity in enclosed and free marine ecosystems showed good agreement. Five phases were characterized by different temperature and salinity regimes in the fjord. A sudden decrease in diatom biomass in upwelled continental coastal water could not be explained on the basis of the ecosystem factors investigated. In the fjord and in enclosures with mixed plankton communities sustained at low phosphate and silicate concentrations reduced phytoplankton activity was observed. We recorded long doubling times of biomass compared with generation times of the dominant species growing at optimal nutrient conditions. Assimilation rate $\left(\mu \mathrm{g} \mathrm{C} \mu \mathrm{g} \mathrm{Chl} \mathrm{a}^{-1} \mathrm{~h}^{-1}\right)$ in mixed plankton communities was normally below 1 ; in diatom cultures it exceeded 1 . During a period of low water temperatures ( 1 to $3^{\circ} \mathrm{C}$ ), assimilation efficiency divided by incident light was significantly linearly correlated with temperature.
\end{abstract}

\section{INTRODUCTION}

In-situ enclosure experiments have become important instruments of experimental plankton ecology since McAllister et al. (1961). Enclosure experiments with natural plankton communities in stratified water columns can be carried out for extended periods of time under nearly natural conditions. Data obtained from such experiments can therefore be extrapolated more reliably to open sea conditions than those from laboratory experiments. Under identical conditions of temperature and light phytoplankton, dynamics reveal considerable parallelism in enclosure and ambient water. The present study aims to (1) characterize the plankton activity in fjord and enclosures on the basis of in-situ production measurements and biomass dis-

\footnotetext{
- This work was supported by 'Deutsche Forschungsgemeinschaft' - Contract AL 46/4 - 'Sonderforschungsbereich 94', Marine Research Hamburg
}

tribution of the phytoplankton; (2) document similarities of the 2 systems in terms of production and biomass distribution.

\section{MATERIAL AND METHODS}

Enclosures, their anchoring, filling as well as sampling procedures have been described by Brockmann et al. (1983) and Brockmann and Hentzschel (1983). Measurements were carried out in a southern Norwegian fjord, Rosfjorden, during early spring (March 2 to April 6), 1979.

\section{Cultivation}

Unialgal, xenic cultures of the 3 locally dominant diatom species, Skeletonema costatum, Thalassiosira nordenskioeldii and Chaetoceros debilis, were started in separate bags during the first week of March. 
Table 1. Inoculation of POSER-monocultures

\begin{tabular}{|c|c|c|c|c|c|c|c|}
\hline \multirow[t]{2}{*}{ Bag } & \multirow[t]{2}{*}{$\begin{array}{l}\text { Volume } \\
\qquad\left(\mathrm{m}^{3}\right)\end{array}$} & \multirow[t]{2}{*}{$\begin{array}{l}\text { Length } \\
\text { (m) }\end{array}$} & \multirow[t]{2}{*}{$\begin{array}{l}\text { Inoculated diatoms } \\
\qquad\left(\times 10^{6} \text { cells }\right)\end{array}$} & \multirow[t]{2}{*}{$\begin{array}{l}\text { Start } \\
\text { (d) }\end{array}$} & \multicolumn{3}{|c|}{$\begin{array}{l}\text { Nutrient addition } \\
\left(\mu \mathrm{g} \text { moles } \mathrm{dm}^{-3}\right)\end{array}$} \\
\hline & & & & & $\mathrm{NO}_{3}^{-}$ & $\mathrm{PO}_{4}{ }^{3-}$ & $\mathrm{SiO}_{2}$ \\
\hline $\mathrm{Y}$ & 15 & 20 & 1250 S. costatum & $18 / 3$ & 12 & 0.7 & 4 \\
\hline z & 15 & 20 & $125 T$. nordenskioeldii & $18 / 3$ & 11 & 0.7 & 8 \\
\hline EE & 4.5 & 10 & 225 C. debilis & $26 / 3$ & 9 & 1.2 & 6 \\
\hline
\end{tabular}

Clones were isolated from the fjord and grown in 51 glass bottles at $15^{\circ} \mathrm{C}$ in the shaded window of a laboratory to densities of $(250,25$ and 25$) \cdot 10^{6}$ cells $\mathrm{dm}^{-3}$; culture medium: membrane-filtered (cellulose nitrate, $0.45 \mu \mathrm{m}$ pore size) fjord water enriched with nutrients according to von Stosch and Drebes (1964). The filtered water within the bags was initially free of algae; it was enriched with nutrients (Table 1).

For inoculation of the plastic bags, exponentially growing cultures were used, after $2 \mathrm{~d}$ adaptation to temperatures of $5^{\circ} \mathrm{C}$ (Table 1 ). Microscopic investigations revealed that the sudden change in temperature did not cause visible damage to the cells.

\section{Primary production}

Samples from fjord and enclosure (Bag U and CC). Borosilicate flasks ( $100 \mathrm{ml}$ ) were filled with water samples taken from depths $0,3,10,20$, and $35 \mathrm{~m}$ at 7 a.m. and $1 \mathrm{p} . \mathrm{m}$. between March 9 and April 2. Depending on plankton density, 4 or $8 \mu \mathrm{Ci} \mathrm{NaH}{ }^{14} \mathrm{CO}_{3}(0.3$ or $0.6 \mathrm{ml}$ solution) were added; and subsequently, the samples were returned to the respective depths. Three flasks (2 light, 1 dark) were incubated at each level. Sampling depths were chosen according to the $1 \%$ light depth at about $40 \mathrm{~m}$. After $6 \mathrm{~h}$ incubation, samples were treated as follows: The whole volume of each flask was membrane-filtered (cellulose nitrate, $0.45 \mu \mathrm{m}$ pore size) at low pressure (Strickland and Parsons, 1972). Membrane filters were then dissolved in $20 \mathrm{ml}$ toluol cocktail (Pugh, 1973) and stored in glass scintillation vials until they were measured by a scintillation counter (Tri Carb Liquid-Scintillation Spectrometer, Packard).

\section{Samples from diatom cultures}

In the monoculture bags, Skeletonema costatum production was measured between March 26 and April 4. The cultures of Thalassiosira nordenskioeldii and Chaetoceros debilis are represented by single primary production measurements only (on March 26, 30 and April 1). The samples were then lowered to the test depths, kept there from 9 a.m. to 6 p.m., and subsequently treated as described above.

\section{Cell counts, chlorophyll and light measurements}

Cell numbers of sub-samples $(10 \mathrm{ml})$ were counted with an inverted microscope, after fixation in $3 \%$ formol. In addition, the morphology of living phytoplankton cells was investigated microscopically. Cell sizes (20 cells of each species) were measured and the main volume per species was calculated using conversion factors from Hagmeier (pers. comm.) and Smetacek (1975).

Chlorophyll measurements were carried out according to Lorenzen (1967). Incident light intensity was calculated using the data of upward directed $2 \pi$-sensors (half spheres with selenium photo elements) submerged at a depth of $5 \mathrm{~m}$ and at the water surface.

\section{RESULTS}

During POSER, diatoms dominated the phytoplankton biomass. Fig. 1 to 7 show the distribution of species and biomass expressed as calculated phytoplankton carbon and measured chlorophyll concentrations in fjord and enclosures. Due to changing water masses, 5 phases with different distribution of phytoplankton species and biomass (carbon and chlorophyll) can be discerned:

Phase 1 (March 2 to 13 ) was characterized by the presence of a nutrient rich (Brockmann et al., 1981; Kattner et al., 1983) upwelled water with a salinity of $\mathrm{S}=33$ to 34 and relatively high temperatures (4 to $5^{\circ} \mathrm{C}$ ) in the euphotic zone, but with low biomass concentrations. The dominant phytoplankton species was Skeletonema costatum.

Phase 2 (March 13 to 20) started with a sudden influx of colder Skagerrak water (of 0 to $2{ }^{\circ} \mathrm{C}$ ) with a salinity below $\mathrm{S} \leq 30$ and low nutrient but high biomass concentrations of mainly ( $\geq 70 \%)$ Thalassiosira nordenskioeldii.

Phase 3 (March 20 to 26) was characterized by upwelling water again. This warmer $\left(3\right.$ to $5^{\circ} \mathrm{C}$ ), saline $(\mathrm{S}=32$ to 34$)$ and nutrient rich water appeared up to 10 to $20 \mathrm{~m}$, containing low biomass concentrations with a 


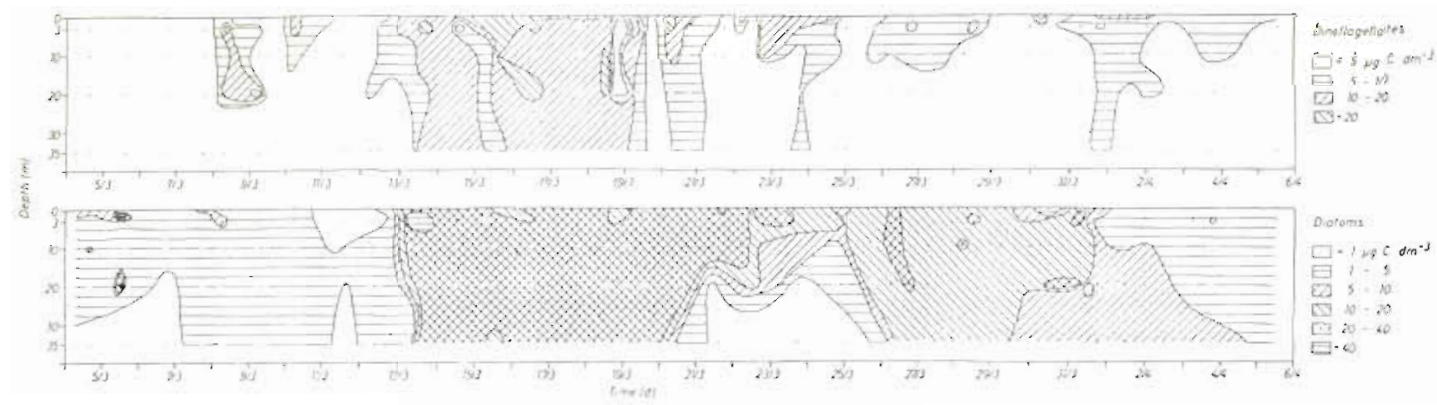

Fig. 1. Biomass of diatoms and dinoflagellates in Rosfjorden durng spring 1979 Concentrations shown by isolınes. Ordinatedepth (m); abscissa: time (d). Small circles: time and depth of sampling
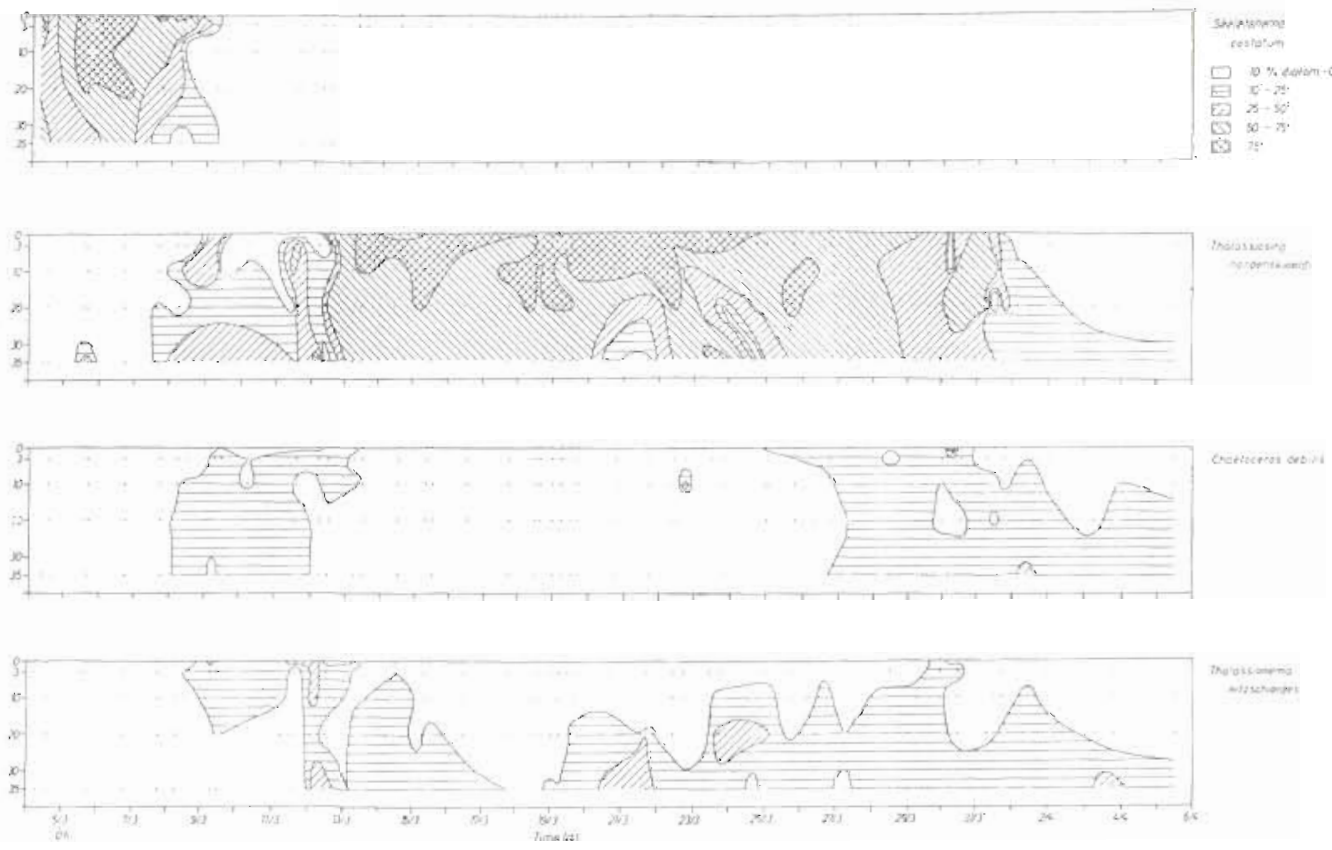

Fig. 2. Percentage distribution ( $\%$ of dıatom biomass) of main diatoms in Rosfjorden: Skeletonema costatum, Thalassiosıra nordenskioeldu, Chaetoceros debilıs, Thalassionema nitzschioides

high percentage of Thalassionema nitzschioides (25 to $50 \%$ ) below $10 \mathrm{~m}$ depth.

Phase 4 (March 26 to 30 ). At the beginning of this phase water masses below $10 \mathrm{~m}$ were replaced again by colder $\left(2\right.$ to $\left.3^{\circ} \mathrm{C}\right)$, less saline $(\mathrm{S}<32)$ and nutrient poor water.

Phase 5 (March 30 to April 6). During the fifth phase water with a low salinity ( $S \leq 32)$ and temperatures from 1 to $3^{\circ} \mathrm{C}$ was found down to depths of 30 to $50 \mathrm{~m}$. Chlorophyll occurred mainly in the euphotic zone (Fig. 7). Despite a decrease in diatom and dinoflagellate biomasses, chlorophyll concentrations remained high, especially in the upper layers.

Enclosure U was set up during the first phase. Until March $7 / 8$ of this phase phytoplankton was mainly

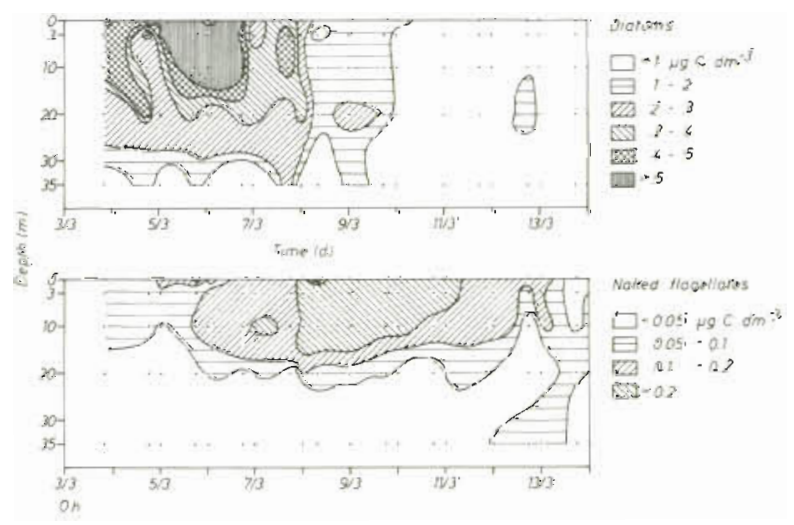

Fig. 3. Biomass of diatoms and naked flagellates in Enclosure U 


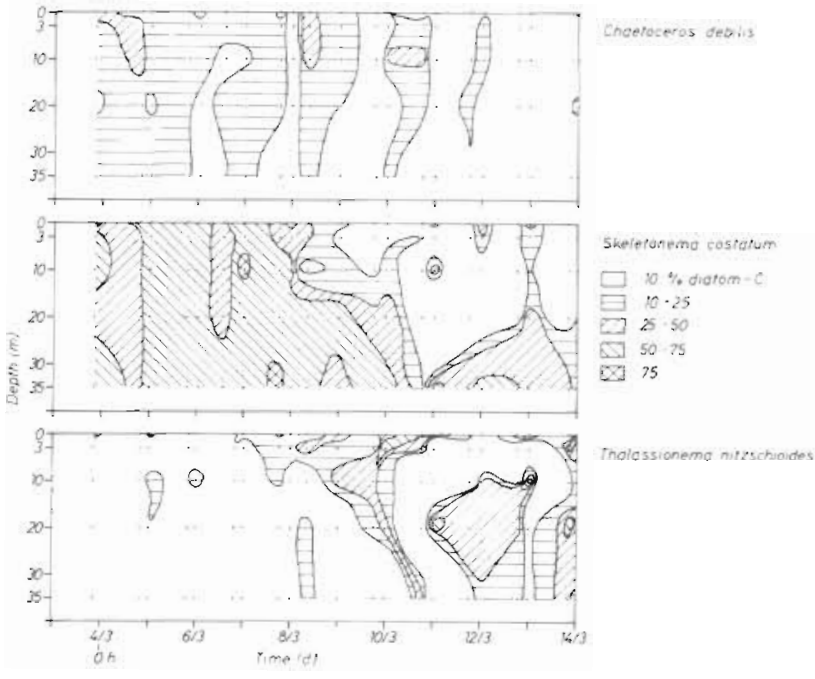

Fig. 4. Biomass of diatoms in Enclosure U. Percentage distribution of main diatoms Skeletonema costatum. Chaetoceros debilis and Thalassionema nitzschioides

represented by Skeletonema costatum in the fjord. Subsequently, an increase of biomass of naked flagellates was observed. The diatom biomass decreased suddenly during this period (Fig. 3). S. costatum accounted for more than $60 \%$ of the biomass during the phytoplankton maximum (Fig. 4). Chaetoceros debilis and Thalassiosira nordenskioeldii contained $20 \%$ and more than $10 \%$ of biomass, respectively. When diatom concentrations decreased to less than $2 \mu \mathrm{g} \mathrm{C} \mathrm{dm}^{-3}$ on March 8 (Fig. 3), the percentage of Thalassionema nitzschioides in total biomass sometimes amounted to $40 \%$ (Fig. 4).

Corresponding to natural stratification, Enclosure CC was filled on March 21 (third phase) with nutrient rich, saline water (Brockmann et al., 1981, 1982) below $14 \mathrm{~m}$ and with Skagerrak water, rich in phytoplankton with low nutrient concentrations in the upper layer
(Kattner et al., 1983). In this upper layer, at first diatoms were the dominant phytoplankton group with more than $20 \mu \mathrm{g} \mathrm{C} \mathrm{dm}^{-3}$, but with a minor component of dinoflagellates (5 to $10 \mu \mathrm{g} \mathrm{C} \mathrm{dm}{ }^{-3}$ ) (Fig. 1 and 5). Along with diatoms dinoflagellates also contributed significantly to the phytoplankton in the fjord during the same time. A few days later, biomass of dinoflagellates exceeded $10 \mu \mathrm{g} \mathrm{C} \mathrm{dm}{ }^{-3}$ in $\mathrm{Bag} \mathrm{CC}$; at a depth of $10 \mathrm{~m}$, just above the lower layer it occasionally reached more than $20 \mu \mathrm{g} \mathrm{C} \mathrm{dm}^{-3}$. As in the upper layer of the fjord on March 21, the dominant diatom in Enclosure $\mathrm{CC}$ was Thalassiosira nordenskioeldii accounting for more than $75 \%$ of the biomass (Fig. 2 and 6). In the lower layer at low phytoplankton concentrations, Thalassionema nitzschioides - the main species - sometimes comprised more than $25 \%$ of the biomass. Chaetoceros debilis represented 10 to $30 \%$ of the biomass within the upper layer around March 27. However, after March 29 the concentrations of diatoms and dinoflagellates decreased; chorophyll remained high, especially in the upper layers (Fig. 7).

The 5 phases are characterized by different patterns of phytoplankton biomass and chlorophyll distribution, and as a consequence more or less distinctly by production (Fig. 8). With respect to primary production a nearly parallel development occurred in the Enclosures $\mathrm{U}$ and $\mathrm{CC}$ compared with the fjord, except on March 13 and 29 when the water masses changed in the fjord.

The calculated phytoplankton biomass in the fjord was very low until the sudden exchange of water masses on March 12/13, yielding C/Chla ratios below 10. Since March 14, C/Chla ratios reached 10 to 20, but were $60 \%$ (average value) lower in comparison to the normal ratio range of 20 to 30 . This was also true for Enclosure CC. Calculated doubling time (from 0 and $3 \mathrm{~m}$ ) of biomass only reached about $15 \mathrm{~h}$ in the fjord and in Tank U (Fig. 9). After March 14 the conditions changed. Biomass doubling times increased to about

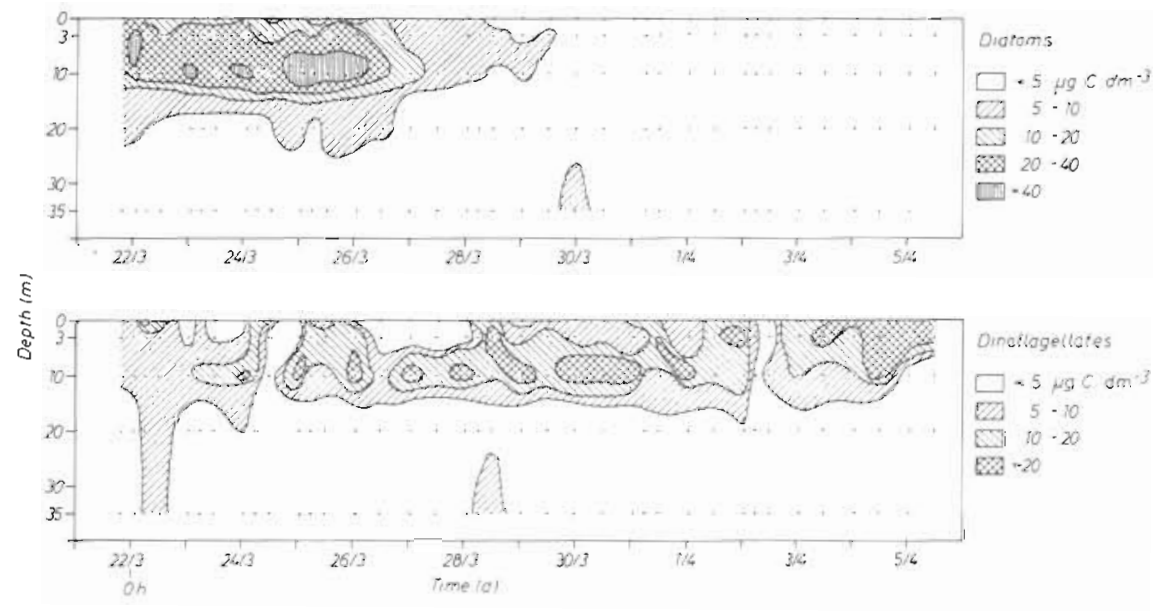

Fig. 5. Biomass of diatoms and dinoflagellates in Enclosure CC 
Fig. 6. Biomass of diatoms in Enclosure CC. Percentage distribution of main diatoms Thalassiosira nordenskioeldii, Thalassionema nitzschioides and Chaetoceros debilis

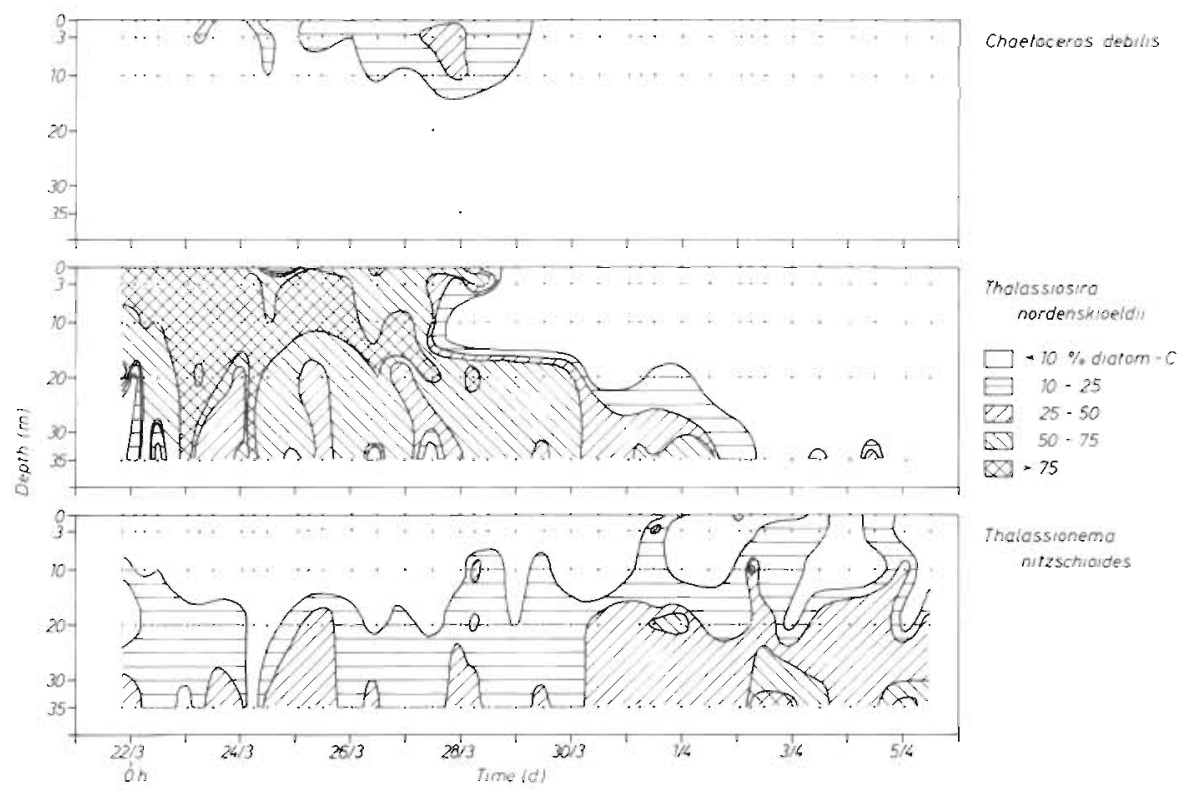

$50 \mathrm{~h}$. Here, too, parallelism between fjord and enclosure was evident.

Assimilation numbers ( $\mu \mathrm{g} \mathrm{C} \mu \mathrm{g} \mathrm{Chla}{ }^{-1} \mathrm{~h}^{-1}$ ) plotted against light (Fig. 10) show an increase at lower depths in nearly all cases with increasing light intensity; most of the primary production took place above a depth of $10 \mathrm{~m}$. Particularly between March 14 and 17, and between March 22 and 24 inhibition occurred; this was evident from surface measurements. Maximum assimilation rates, $K_{\max }$, were calculated as means of nearsurface values when productivity was reduced at the surface. $K_{\max }$ rates were lowest on March 22 with
$0.15 \mu \mathrm{g} \mathrm{C} \mu \mathrm{g} \mathrm{Chla} \mathrm{g}^{-1} \mathrm{~h}^{-1}$; they did not exceed 0.75 throughout the experiment (Fig, 11).

Temperature dependence of productivity is shown best by calculating productivity and assimilation rates at 0 and $3 \mathrm{~m}$, divided by corresponding light values; giving a highly significant linear correlation with water temperatures between 1 and $5^{\circ} \mathrm{C}$ until March 26 (Fig. 12).

Contrary to the very low productivity of natural plankton communities, diatom bag cultures, especially Skeletonema costatum (Bag Y), grew under optimal nutrient conditions. This species attained a biomass of
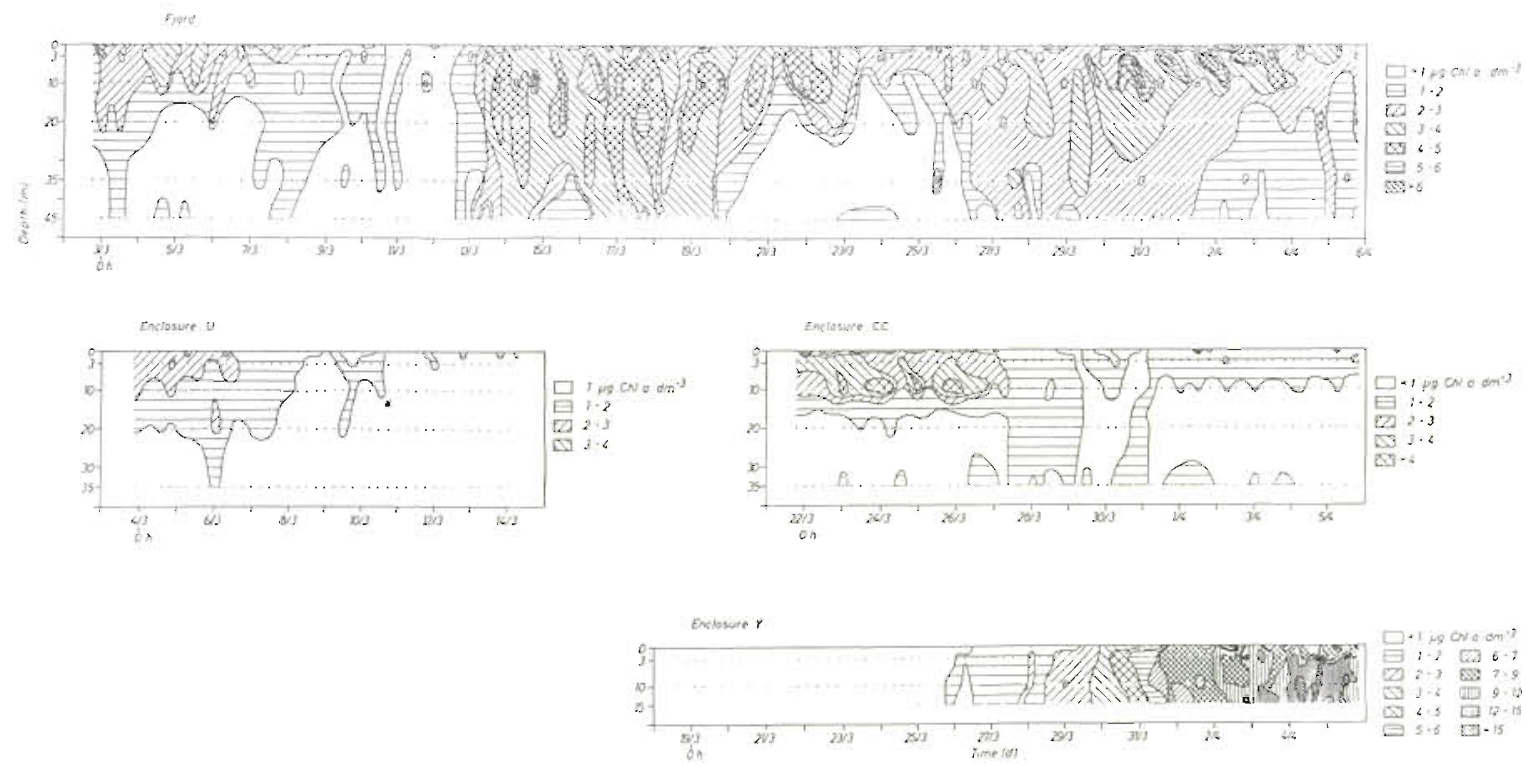

Fig. 7. Chlorophyll a concentration $\left(\mu \mathrm{g} \mathrm{dm}^{-3}\right)$ in Rosfjorden and enclosures, shown by isolines as a function of depth (abscissa) and time (ordinate) 


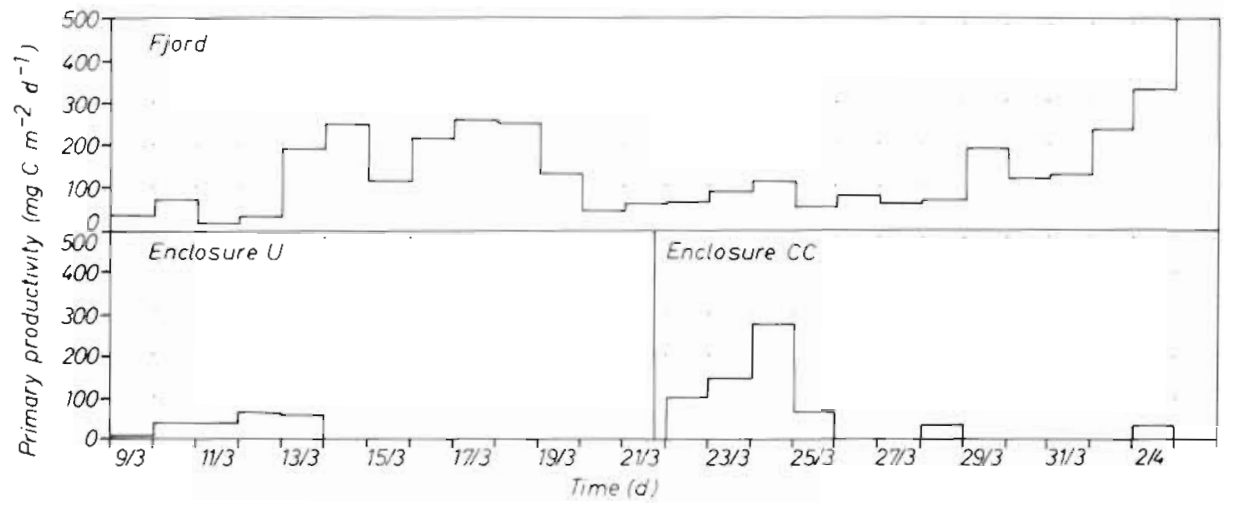

Fig. 8. Primary productivity (mg C $\mathrm{m}^{-2} \mathrm{~d}^{-1}$ ) in Rosfjorden and Enclosures $\mathrm{U}$ and $\mathrm{CC}$

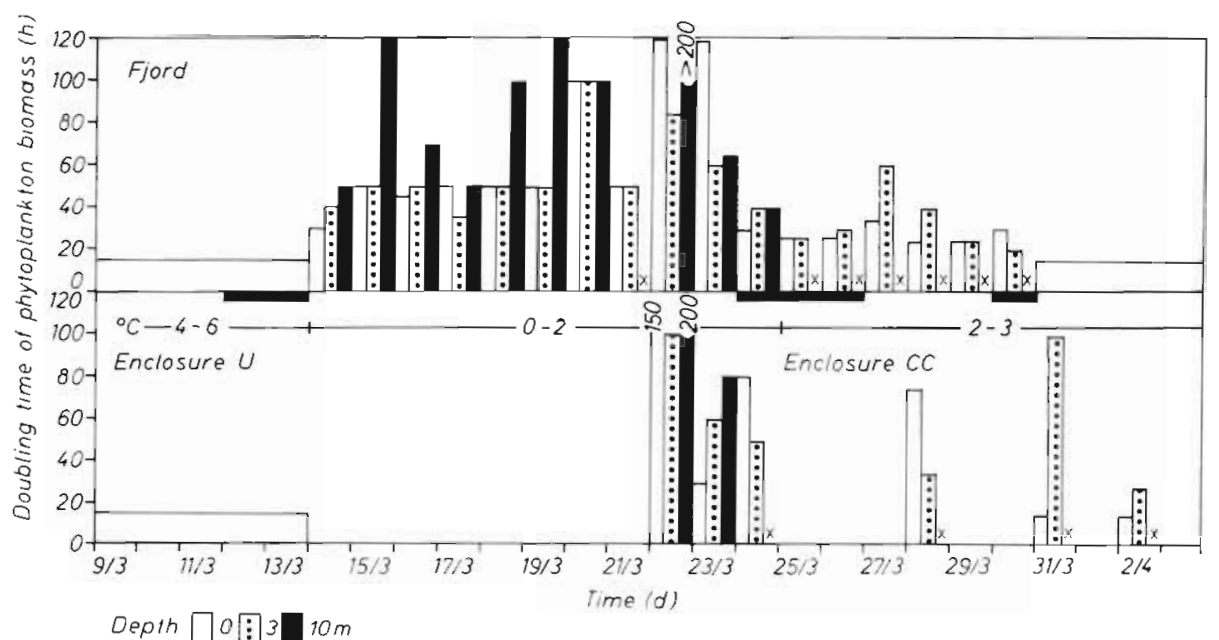

Fig. 9. Doubling times of biomass (phytoplankton without nanoflagellates) from Rosfjorden and Enclosures $\mathrm{U}$ and $\mathrm{CC}$. Horizontal black bars: changes in water masses. Crosses: $10 \mathrm{~m}$ values are not Depin 0 : $310 \mathrm{~m}$ calculated

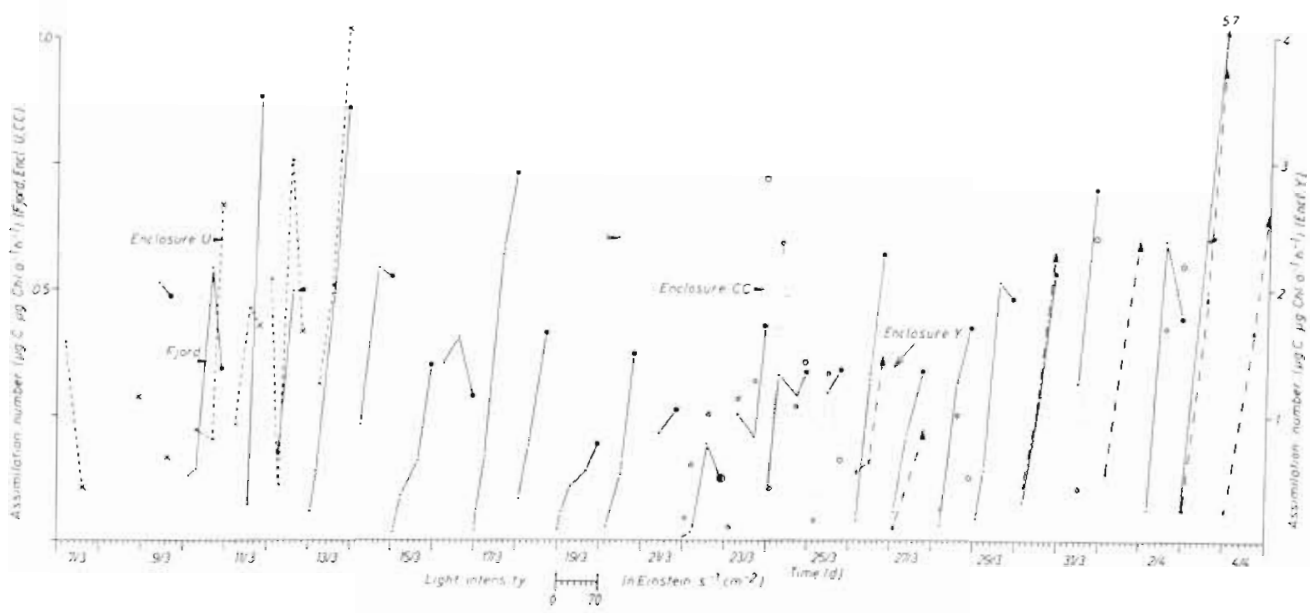

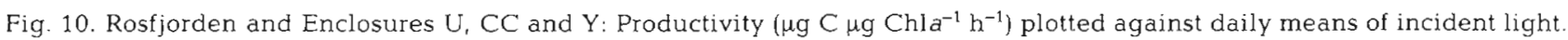
Productivity values of Enclosure $Y$ on a reduced scale. Values plotted with increasing depths $(0,3,10,20,35 \mathrm{~m})$ from right to left

Surface measurements are indicated by larger symbols. Only from lower depths were some measurements not performed

more than $700 \mu \mathrm{g} \mathrm{C} \mathrm{dm} \mathrm{m}^{-3}$ (35 $10^{6}$ cells $\left.\mathrm{dm}^{-3}\right)$ at the end of experiment (Fig. 13). Exponential growth stopped first at the water surface (April 3). Maximum primary production occurred at 0 and $3 \mathrm{~m}$ (Tab. 2). Within $8 \mathrm{~d} S$. costatum increased from $200 \mathrm{mg} \mathrm{C} \mathrm{m}^{-2}$ $\mathrm{d}^{-1}$ (March 26) to $3000 \mathrm{mg} \mathrm{C} \mathrm{m} \mathrm{m}^{-2} \mathrm{~d}^{-1}$ (April 3). This corresponds to a doubling time of $40 \mathrm{~h}$ (determined by increase in cell number). Generation time near the surface at light saturation was $34 \mathrm{~h}$. In the upper depths, production ( $\mu \mathrm{g} \mathrm{C} \mu \mathrm{g} \mathrm{Chla} a^{-1} \mathrm{~h}^{-1}$ ) was in the 


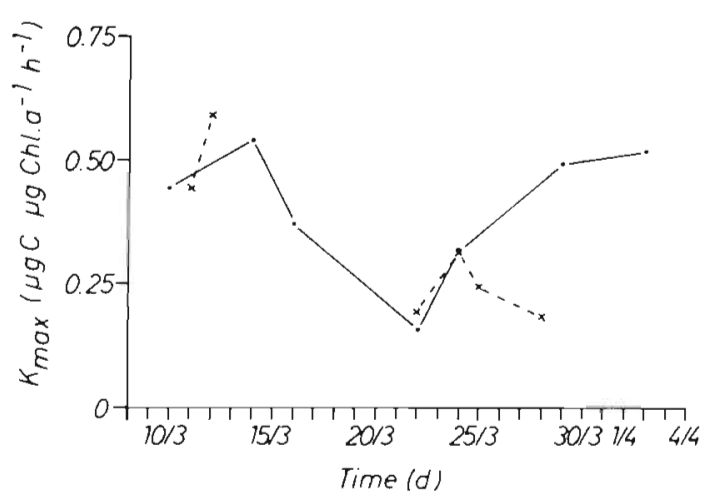

Fig. 11. Maximum assimilation numbers $\left(\mathrm{K}_{\mathrm{max}}\right)$ calculated as means of near-surface values from the fjord (straight line) and from Enclosures U and CC (hatched line)

expected range of $>1$ (Fig. 10). In contrast to $S$. costatum, no light dependence of production occurred for Thalassiosira nordenskioeldii (Bag Z) down to depths of $10 \mathrm{~m}$ (Table 2).

Table 2. Primary productivity, expressed as mg C $10^{-8} \mathrm{cells}^{-1}$ $\mathrm{h}^{-1}$ of diatom monocultures (Enclosures $\mathrm{Z}, \mathrm{EE}$ and $\mathrm{Y}$ )

\begin{tabular}{|c|c|c|c|}
\hline $\begin{array}{l}\text { Depth } \\
\text { (m) }\end{array}$ & $\begin{array}{c}\text { T. nordenskioeldii } \\
\mathrm{Z}\end{array}$ & $\begin{array}{l}\text { C. debilis } \\
\mathrm{EE}\end{array}$ & $\begin{array}{c}\text { S. costatum } \\
\mathrm{Y}\end{array}$ \\
\hline 0 & 2.5 & $0.32 \pm 0.03$ & $0.08 \pm 0.02$ \\
\hline 3 & $2.1 \pm 0.5$ & $0.37 \pm 0.03$ & $0.07 \pm 0.03$ \\
\hline 10 & 2.25 & - & $0.03 \pm 0.01$ \\
\hline 15 & - & - & $0.02 \pm 0.00$ \\
\hline
\end{tabular}

\section{DISCUSSION}

It is well documented that there are plankton spring blooms of Skeletonema costatum in temperate northern coastal regions similar to those observed in the first phase and of Thalassiosira nordenskioeldii populations dominating at lower temperatures (Hitchcock and Smayda, 1977; Paasche and Østergren, 1980). These observations were confirmed during the change of water masses on March $12 / 13$ with decrease of temperature and increase of $T$. nordenskioeldii cell numbers (Fig. 2).

Comparison of photosynthesis rate per Skeletonema

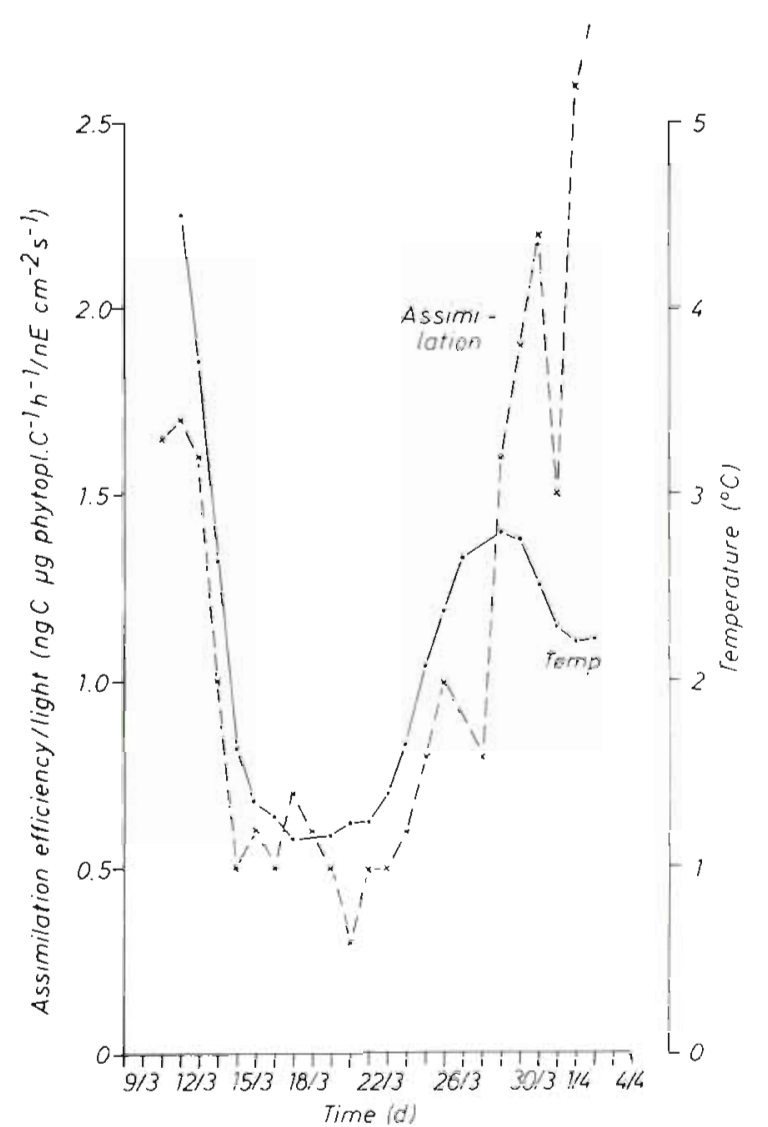

Fig. 12. Water temperature (straight line) and assimilation efficiency per unit light (ng $C \mu \mathrm{g}$ phytoplankton- $\mathrm{C}^{-1} \mathrm{~h}^{-1} / \mathrm{nE}$ $\mathrm{cm}^{-2} \mathrm{~s}^{-1}$ ) (hatched line) in Rosfjorden. Means of 0 and $3 \mathrm{~m}$ measurements were smoothed forming running means of 3 values each

costatum cell in the bag cultures at 2 to $3^{\circ} \mathrm{C}$ (Table 2) with the photosynthesis rate from the fjord (March 5 to $7)$ at 4 to $5^{\circ} \mathrm{C}$ when $S$. costatum was dominant $(0.25$ [0.4 max] $\mathrm{mg} \mathrm{C} 10^{-8}$ cells ${ }^{-1} \mathrm{~h}^{-1}$ ) indicates an underestimation of production in the fjord caused by neglection of nanoflagellates. This is due to a 2 -fold increase in productivity which could be expected from the linear correlation of productivity and temperature resulting from mixed plankton without $S$. costatum (Fig. 12). Nanoplankton should account for 20 to $30 \%$ of the total phytoplankton biomass. This is confirmed by coulter counter countings (Kuiper et al., 1980) and by microscopic observations of the living plankton.

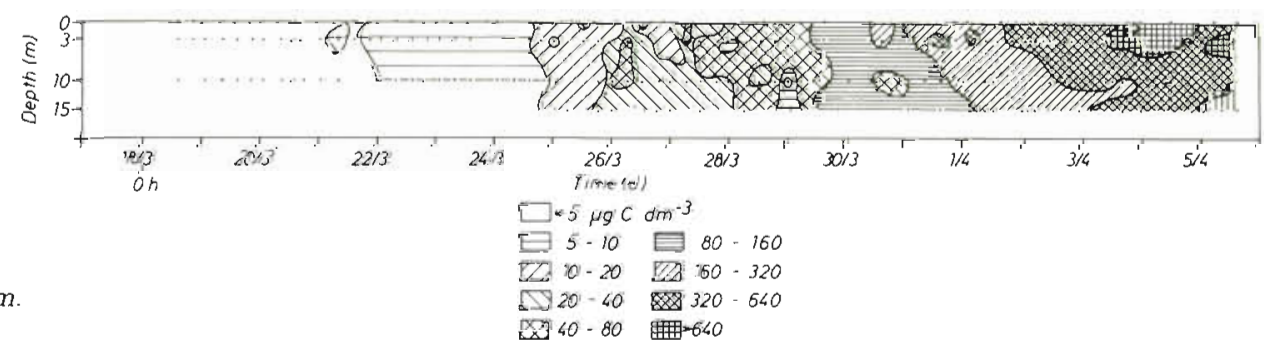

Fig. 13. Skeletonema costatum. Biomass in Enclosure $Y$ 
Nanoplankton also seemed to be responsible for a productivity-increase in the fjord during the last phase of experiment (Fig. 8). The decrease of diatom biomass during this period was caused by grazing losses (Kattner et al., 1983). This does not explain, however, the sudden decrease of diatom numbers in both fjord and Bag $U$ during the first phase (Fig. 2 and 3). Nutrient limitation is unlikely. The influence of heavy metals was discussed in this regard because upwelling water was found in the fjord at this time (Brockmann et al., 1981). However, Skeletonema costatum had achieved a cell number of $4 \times 10^{5}$ cells $\mathrm{dm}^{-3}$ before the observed decline in living cells. The increase of naked flagellates (Fig. 3) with concomitant decrease of diatom numbers indicates the end of a phytoplankton bloom as reported by Skjoldal and Lännergren (1978), limited by factors other than macronutrients.

The results of the period between the second and fifth phase show no prolonged exponential growth of phytoplankton. Comparison of doubling times of biomass with generation times of the dominating species established in laboratory cultures (Table 3) partly reveals a significant decrease in phytoplankton activity in the fjord and in Enclosure CC. The major cause appears to be a more or less persistent nutrient deficiency. In this regard the second phase in the nutrient-depleted upper layer (Brockmann et al., 1981, 1982) ( 0 and $3 \mathrm{~m}$ ) in the fjord can be compared with the conditions in continuous cultures with limiting nutrient concentrations. Longer doubling times of the biomass were found from depths around $10 \mathrm{~m}$. The results from the culture experiment with Thalassiosira nordenskioeldii show that there was light saturation in $10 \mathrm{~m}$ depth (Tab. 2). About $14 \%\left(7 \mathrm{nE} \mathrm{cm}^{-1} \mathrm{~s}^{-1}\right)$ of the surface light which is saturating for generation times at these low temperatures were measured at a depth of $10 \mathrm{~m}$ (Durbin, 1974; Baars, 1981). The influence of the daylength can also be of great importance (Durbin, 1974), but detailed microscopic observations showed, beginning on March 21 in the fjord, a high percentage of dead cells within the chains at a depth of $10 \mathrm{~m}$. These cells were probably sedimented from the nutrient depleted upper layers. At the $10 \mathrm{~m}$ level the nutrient concentrations increased at this time (Brock- mann et al., 1981). Sinking rates of some meters per day, especially of damaged cells, have been reported (Smayda, 1970). Therefore it can be considered that calculation of doubling times at $10 \mathrm{~m}$ depth revealed reduced activity due to the high number of dead cells at this depth.

The question which nutrient or which combination of nutrients caused a limitation effect on the plankton activity may be approached by observation of cell morphology. In fjord and Bag CC, cells of Thalassiosira nordenskioeldii were closely packed in the chains. Thomas et al. (1980) observed similarly structured chains, for instance during silicate deficiency of $T$. nordenskioeldii. As the cells showed no chlorosis during the POSER experiment, nitrate or an enhanced phosphate deficiency was unlikely (Holmes, 1966). In the upper euphotic zone phosphate and silicate con-

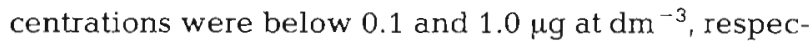
tively (Brockmann et al., 1981, 1982), leading to a Si:P ratio $(w t / w t)$ of 10 . This was the nutrient consumption ratio of Skeletonema costatum in the bag culture (Eberlein et al. 1983). Sander and Moore (1979) suggested silicate to be limiting at $\mathrm{Si}: \mathrm{P}$ ratios (wt/wt) below 25 .

Often the chloroplasts of the diatom cells were darkish brown, indicating a higher pigment content (for review see Werner, 1977) which can rise by a factor of 2 at silicate depletion, as could be shown at the beginning of the stationary phase of Thalassiosira nordenskioeldii cultures (Jahnke, 1982). In spite of the concomitantly increasing carbon content, the $\mathrm{C} / \mathrm{Chla}$ ratio of such cells would be lowered by $30 \%$. Data by Dahl et al. (1983) indicate that at least phosphate was a limiting nutrient. Therefore a limitation of both, silicate and phosphate, or a frequent changing of limitation between these 2 nutrients is suggested.

Due to lacking nutrients the low assimilation rates below or near 1 are not surprising. At low temperatures, assimilation rates between 1 and 4 can be expected (Saijo and Ichimura, 1962; Platt and Rao, 1970; Durbin et al., 1975; Takahashi et al., 1978). This is well confirmed by the data from the bag culture of Skeletonema costatum at sufficiently high nutrient concentrations. Direct influence of low temperature on

Table 3. Generation times at light saturation of diatom species in laboratory cultures

\begin{tabular}{|c|c|c|c|}
\hline \multirow[t]{2}{*}{ Species } & \multicolumn{3}{|c|}{ Temperature $\left({ }^{\circ} \mathrm{C}\right)$} \\
\hline & 0 & $2-3$ & $4-5$ \\
\hline S. costatum & & $32.1 \quad(29.7-34.8)$ & $16 \quad(2) ; 24$ \\
\hline T. nordenskioeldii & $\begin{array}{l}48 \quad(4) \\
35-55 \quad \text { (1) size dependent }\end{array}$ & $30.0 \quad(28.3-31.9\}$ & $20-30$ (1) size dependent \\
\hline C. debilis & \multirow[b]{2}{*}{$42 \quad(3)$} & $39.4 \quad(34.5-45.9)$ & - \\
\hline T. nitzschioides & & - & - \\
\hline
\end{tabular}


phytoplankton activity was well documented here by controlled experiments under natural conditions, as is seen from a highly significant correlation between water temperature and productivity. A linear relation was also reported to be acceptable by Harrison and Platt (1980) who found temperatures influencing most dominant assimilation rates.

The present investigations show that the spring bloom processes at the Norwegian south coast could be very complex. Coastal currents will bring along water bodies with plankton populations at different stages of development. Due to changes of air pressure, wind forces and direction, upwelling water will be brought in between coastal water masses interrupting processes of a steady spring bloom, as was observed in the open sea at nearly the same latitude during April 1976 (FLEX) (Wandschneider, 1983). Decrease in incident light and temperature may also retard exponential phytoplankton growth during early spring. Influences of water exchange and different weather regimes on plankton development in an open fjord could be distinguished by enclosing parts of the different water masses in bags.

Acknowledgements. We are grateful to Professor F. Liemann for help in conducting ${ }^{14} \mathrm{C}$ analyses; to I. Büns, G. Kramm, R. Lucht, A. Pfeiffer and G. Oberländer for technical assistance; and to $\mathrm{B}$. Kronberg for reading the manuscript. For a discussion of the manuscript we thank W. W. C. Gieskes.

\section{LITERATURE CITED}

Baars, J. W. M. (1981). Autecological investigations on marine diatoms. II. Generation times of 50 species. Hydrobiol. Bull. 15: 137-151

Brockmann, U. H., Hentzschel, G. (1983). Samplers for enclosed stratified water columns. Mar. Ecol. Prog. Ser. 14: $107-109$

Brockmann, U. H., Koltermann, K. P., Dahl, E., Dahle, A., Eberlein, K., Gaertner, A., Gassmann, G., Hammer, K. D., Jahnke, J., Kattner, G., Krause, M., Kuiper, J., Laake, M., Nagel, K. (1981). Water exchange in Rosfjorden during spring '79. A detailed account of physical, chemical and biological variations. In: Saetre, R., Mork, M. (ed.) The Norwegian coastal current. University of Bergen, p. $93-130$

Brockmann, U. H., Kattner, G., Dahl, E. (1982). Plankton spring development in a south Norwegian fjord. In: Grice, G. D., Reeve, M. R. (ed.) Marine mesocosms. Springer, New York, p. 195-204

Brockmann, U. H., Dahl, E., Kuiper, J., Kattner, G. (1983). The concept of POSER (Plankton observation with simultaneous enclosures in Rosfjorden). Mar. Ecol. Prog. Ser. 14: 1-8

Dahl, E., Laake, M., Tjessem, K., Eberlein, K., Bøhle, B. (1983). Effects of Ekofisk crude oil on an enclosed planktonic ecosystem. Mar. Ecol. Prog. Ser. 14: 81-91

Durbin, E. G. (1974). Studies on the autecology of the marine diatom Thalassiosira nordenskioeldii CLEVE. I. The influence of daylength, light intensity, and temperature on growth. J. Phycol. 10: 220-225
Durbin, E. G., Krawiec, R. W., Smayda, T. J. (1975). Seasonal studies on the relative importance of different size fractions of phytoplankton in Narragansett Bay (USA). Mar. Biol. 32: 271-287

Eberlein, K., Brockmann, U. H., Hammer, K. D., Kattner, G., Laake, M. (1983). Total dissolved carbohydrates in an enclosure experiment with unialgal Skeletonema costatum culture. Mar. Ecol. Prog. Ser. 14: 45-58

Falkowski, P. G. (1977). The adenylate energy charge in marine phytoplankton. The effect of temperature on the physiological state of Skeletonema costatum. J. exp. mar. Biol. Ecol. 27: 37-45

Hagmeier, E. (1973). Estimated values for the carbon content of plankton, used in the plankton laboratory of the Marine Biological Station, Helgoland (pers. comm.)

Harrison, W G., Platt, T. (1980). Variations in assimilation number of coastal marine phytoplankton: effects of environmental co-variates. J. Plankton Res. 2: 249-260

Hitchcock, G. L., Smayda, T. J. (1977). The importance of light in the initiation of the 1972-1973 winter-spring diatom bloom in Narragansett Bay. Limnol. Oceanogr. 22: 126-131

Holmes, R. W. (1966). Light microscope observations on cytological manifestations of nitrate, phosphate, and silicate deficiency in four marine centric diatoms. J. Phycol. 2: $136-140$

Jahnke, J. (1982). Laborversuche zur Beziehung zwischen Wachstums- und Photosyntheserate von sechs planktischen, marinen Diatomeenarten unter Bericksichtigung der Übertragbarkeit auf ,in situ" Tankkulturen und die natürlichen Planktongemeinschaften im Rosfjord/Südnorwegen. Diss. Math.-Naturw. Fakultät RWTH Aachen, Aachen, pp. 169

Kattner, G., Hammer, K. D., Eberlein, K., Brockmann, U. H., Jahnke, J., Krause, M. (1983). Nutrient and plankton development in Rosfjorden and enclosed ecosystems captured from the changing water bodies during POSER. Mar Ecol. Prog. Ser. 14: 29-43

Kuiper, J., Hoornsman, G., Roele, P., van't Groenewoud, H. (1980). Plankton observations in simultaneous enclosures at Rosfjord. TNO rep. no. CL 80/80: 1-73

Lorenzen, C. J. (1967). Determination of chlorophyll and pheopigments. Spectrophotometric equations. Limnol. Oceanogr. 12: 343-346

McAllister, C. D., Parsons, T R., Stephens, K., Strickland, J. D. H. (1961). Measurements of primary production in coastal sea water using a large-volume plastic sphere. Limnol. Oceanogr. 6: 237-258

Paasche, E., Østergren, I. (1980). The annual cycle of plankton diatom growth and silica production in the inner Oslofjord. Limnol. Oceanogr. 25: 481-494

Platt, T., Rao, D. V. S. (1970). Primary production measurements on a natural plankton bloom. J. Fish. Res. Bd Can. 27: 887-899

Pugh, P. R. (1973). An evaluation of liquid scintillation counting techniques for use in aquatic primary production studies. Limnol. Oceanogr. 18: 310-319

Saijo, Y., Ichimura, S. (1962). Some considerations on photosynthesis of phytoplankton from the point of view of productivity measurements. J. oceanogr. Soc. Japan; 20th Anniversary Volume: 689-693

Sander, F., Moore, E. (1979). Significance of ammonia in determining the N:P ratio of the sea water off Barbados, West Indies. Mar. Biol. 55: 17-21

Schöne, H. (1977). Die Vermehrungsrate mariner Planktondiatomeen als Parameter in der Ókosystemanalyse. Math.-Nat. Fakultät RWTH Aachen, Aachen 
Skjoldal, H., Lännergren, C. (1978). The spring phytoplankton bloom in Kindärspollene, a land-locked Norwegian fjord. II. Biomass and activity of net- and nanoplankton. Mar. Biol. 47: 313-323

Smayda, T. J. (1970). The suspension and sinking of phytoplankton in the sea. Oceanogr. mar. Biol. A. Rev. 8: $353-414$

Smetacek, V. (1975). Die Sukzession des Phytoplanktons in der westlichen Kieler Bucht. Thesis, University of Kiel

Stosch, von, H. A., Drebes, G. (1964). Entwicklungsgeschichtliche Untersuchungen an zentrischen Diatomeen IV. Die Planktondiatomee Stephanopyxis turris, ihre Behandlung und Entwicklungsgeschichte. Helgoländer wiss. Meeresunters. 11: 209-257

Strickland, J. D. H., Parsons, T. R. (1972). A practical handbook of seawater analysis. Fish. Res. Bd Can. 167: 1-310

Takahashi, M., Barwell-Clarke, J., Whitney, F., Koeller, P.
(1978). Winter conditions of marine plankton populations in Saanich Inlet, B. C., Canada. I. Phytoplankton and its surrounding environment. J. exp. mar. Biol. Ecol. 31: 283-301

Thomas, W. H., Hollibaugh, J. T., Seibert, D. L. R. (1980). Effects of heavy metals on the morphology of some marine phytoplankton. Phycologia 19: 202-209

Wandschneider, K. (1983). Some biotic factors influencing the succession of diatom species during FLEX '76. In: Sündermann, J., Lenz, W. (ed.) North Sea dynamics. Springer, Berlin-Heidelberg-New York, p. 573-583

Werner, D. (ed.) (1977). The biology of diatoms. Botanical monographs 13. Blackwell, Berkeley

Yoder, J. A. (1979). Effect of temperature on light-limited growth and chemical compositions of Skeletonema costatum (Bacillariophyceae). J. Phycol. 15: 362-370

This paper was submitted to the editor; it was accepted for printing on August 4, 1983 